\title{
Recaizade Mahmut Ekrem'in Sadullah Paşa'ya Yazdığı Mektuplar ve Edebiyat Tarihi Açısından Bir Değerlendirme
}

\section{Recaizade Mahmut Ekrem's Letters to Sadullah Pasha and an Examination in the Context of Literary History}

\author{
Şerif ESKIN ${ }^{1}$ (])
}

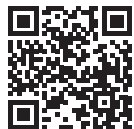

'Sorumlu yazar/Corresponding author: Şerif Eskin (Dr. Öğr. Üyesi),

Istanbul Üniversitesi, Edebiyat Fakültesi,

Türk Dili ve Edebiyatı Bölümü, İstanbul, Türkiye

E-posta: eskinserif@istanbul.edu.tr

ORCID: 0000-0001-8418-6970

Başvuru/Submitted: 25.09 .2020

Revizyon Talebi/Revision Requested:

01.10 .2020

Son Revizyon/Last Revision Received:

06.10.2020

Kabul/Accepted: 19.10 .2020

Online Yayın/Published Online: 30.11.2020

Atıf/Citation: Eskin, Serif. "Recaizade Mahmut Ekrem'in Sadullah Paşa'ya Yazdığı Mektuplar ve Edebiyat Tarihi Açısından Bir Değerlendirme." Türkiyat Mecmuası-Journal of Turkology 30, 2 (2020): 505-530.

https://doi.org/10.26650/iuturkiyat.803428

\section{ÖZ}

Bu çalışmada, Recaizade Mahmut Ekrem'in Sadullah Paşa'ya yazdığı ve bugüne dek kaynaklarda yer almayan kimi mektuplar yayımlanıp edebiyat tarihi açısından değerlendirilecektir. Genel olarak bakıldığında, mektupların muhtevalarının kişisel konulardan ibaret olmadığı, yazışmalarda edebî modernleşme hakkında bir müzakerenin yürütüldüğü, edebiyat tarihinin başlıca tartışma konuları üzerine mülâhazalarda bulunulduğu görülecektir. Bu bakımdan incelenecek mektuplar belgesel değere sahiptir. Sadullah Paşa'nın yayımlanmamış şiirleri, yazıları ve çevirileri kaybolduğu için onun edebî kimliği ve etki alanı hakkındaki bilgiler sınırlı düzeyde kalmıştı. Dolayısıyla bu mektuplardaki veriler onun günümüze yansıyan portresini bir parça daha aydınlatacaktır. Ayrıca başka önemli yazarlar üzerinde etkili olduğu bilinen Sadullah Paşa'nın Recaizade Mahmut Ekrem ile olan diyalogu ve etkileşimi de bu mektuplar sayesinde tespit edilip değerlendirilmiş olacaktır. Recaizade Mahmut Ekrem'in kitaplarına girmemiş bir şiiri de söz konusu mektuplar vesilesiyle ortaya çıkarılmıştır. İki isim arasındaki fikir alışverişinde Recaizade, edebiyatta modernleşmenin önündeki en önemli engelleri; Osmanlı kültür dünyasında edebî eleştirinin yokluğu, şiir dilinin nesir dilindeki gelişmelerden geri kalması, aruz vezninin Türkçenin doğasına aykırı olması, kadim Osmanlı edebiyatı üzerine yeterince araştırma yapılmaması olarak sıralar. Sadullah Paşa ise Türk boylarının medeniyet yoluna girdikten sonra Arap ve Acem şairleri taklit ederek Türk edebiyatını geliştirdiklerini ancak bunu yaparken Türk şiirinin "hâssa-i kavmiyyesini" muhafaza edemediklerini ileri sürer. Anahtar kelimeler: Sadullah Paşa, Recaizade Mahmut Ekrem, şiir, eleştiri, edebiyatta modernleşme

\section{ABSTRACT}

In this study, some of Recaizade Mahmut Ekrem's letters to Sadullah Pasha that have not been included in the sources until today will be published and evaluated in the context of literary history. In a general overview, it is seen that the content of these letters is not limited to personal matters, they conduct a negotiation on literary modernization, and there are some considerations on the main matters of debate on the history of literature. Concordantly, these letters in question have a documental value. As Sadullah Pasha's unpublished 
poems, writings and translations are lost, information about his literary personality and scope remained limited. Therefore, the data in these letters will shed further light on his portrait today. Moreover, the dialogue and interaction between Recaizade Mahmut Ekrem and Sadullah Pasha, whose influence on other important writers is known, are identified and evaluated via these letters. One of Recaizade Mahmut Ekrem's poems that is not included in his books was also revealed owing to these letters. In the exchange of ideas between these two figures, Recaizade specifies that the most important obstacles to modernization in literature are the absence of literary criticism in the Ottoman cultural world, the lagging of language of poetry behind the developments in the language of prose, the contradiction between the aruz prosody and the nature of Turkish language, and inadequate research conducted on ancient Ottoman literature. On the other hand, Sadullah Pasha suggests that Turkic tribes improved Turkish literature by imitating Arabian and Persian poets on the way to civilization, but could not preserve the "national characteristic" of Turkish poetry in the meanwhile.

Keywords: Sadullah Pasha, Recaizade Mahmut Ekrem, poetry, literary criticism, literary modernization

\section{EXTENDED ABSTRACT}

The letters have been very functional instruments in regard to providing various opportunities for dialogue, and opening negotiation and interaction areas to master writers in the modern era literary public. When we look at the voluminous correspondences of Namik Kemal, the exchange of letters between Fatma Aliye and Ahmet Mithat Efendi, the controversy between Abdülhak Hamid and Recaizade Mahmut Ekrem regarding Nesteren and many other cases, especially during the formation period of modern Ottoman literature, a vivid dialogue and interaction via letters attract attention. In this article, Recaizade Mahmut Ekrem's letters to Sadullah Pasha which have not been included in sources until today and are published here for the first time, are analyzed in the related context.

As in the case of many examples, writers' letters are amongst the primary sources of literature history. In Orhan Okay's words, private letters have documental features and they shed light on their era, personages, interpersonal relations, and many unknown stages in the background of art works; thus, they are an important source for biographical research.

When we look at the correspondence between these two important figures in Ottoman literature during the modernization period - Recaizade Mahmut Ekrem and Sadullah Pasha - it is seen that the content of these letters is not limited to personal matters, there is a vivid discussion on the construction of a new literary tradition and literary modernization, and considerations on the main matters of debate in the literary history. In this regard, these letters in question have a documental value.

Information about Sadullah Pasha's literary personality and scope is limited because after his suicide, his unpublished poems, writings and translations were lost. Therefore, the data obtained from these letters in this article, will shed further light on his portrait today. Moreover, Sadullah Pasha is known to have an influence on other important writers such as Abdülhak Hâmid, and his dialogue and interaction with Recaizade Mahmut Ekrem are identified and evaluated via these letters. One of Recaizade Mahmut Ekrem's poems which is not included in his books and passed on until today, was also revealed owing to one of those letters and is analyzed in this article. 
An outstanding agenda item, especially in the letters dated 1879, was "progress in literature". "Progress" [terakki] was a characteristic term of the $19^{\text {th }}$ century and onwards and was a keyword in literary discussions. The purpose of progress in literature here, as it is understood, is to construct a new literature following the example of modern literature blooming in the West.

In the exchange of ideas between these two figures, Recaizade specifies that the most important obstacles to modernization in literature are the absence of literary criticism in the Ottoman cultural world, the lagging of language of poetry behind the developments in the language of prose, the contradiction between the aruz prosody and the nature of Turkish, and inadequate research conducted on ancient Ottoman literature. If we broach his views, it is the nature of the aruz prosody that drags Ottoman poets to tumturak- $l$ elfaz obsession and even forcefully leads them to this direction because aruz prosody is at variance with Ottoman Turkish. If the syllabic meter replaces aruz prosody, misdeeds such as unfamiliar usage of compound phrases are prevented. Thus, the beauty of meaning and clarity of meaning will be provided in regard to rhetoric. According to him, there has been great progress in the language of prose and in line with this progress, it is possible to write a novel appropriate for the current circumstances of that period. However, it is not possible to write a drama in verse, as aruz prosody withstands the structure of Ottoman Turkish. According to Recaizade, another condition to advance in literature depends on research and studies on classical Ottoman literature. In fact, he would also make an effort in 1879, when he wrote these lines, by writing Talim-i Edebiyat, and Kudemâdan Birkaç Şair a while later.

On the other hand, Sadullah Pasha suggests that Turkic tribes improved Turkish literature by imitating Arabian and Persian poets on the way to civilization but could not preserve the "national characteristic" of Turkish poetry in the meanwhile. Sadullah Pasha's propounded ideas remind us of the suggestions of the nationalist criticism that bloomed at the threshold of $20^{\text {th }}$ century and can be considered as one of their premises. During the Meşrutiyet and Republican period, one of the primary criticisms addressed towards Ottoman literature was that it was a cosmopolitan literature rather than a national literature.

Because of the conducted research and investigation, it is believed that the letters written by Recaizade Mahmut Ekrem to Sadullah Pasha are not limited to those mentioned here. It is hoped that the other letters and documents of these two personages will be revealed and will fill the gaps in the history of literature and clear the way for new studies.

The subject-case of this article, also confronts us with the problematic of accessing resources in the history of Turkish literature studies. It is a known fact that many works and documents like those mentioned here are not open to access as they are kept in private collections or archives. For this reason, the future steps to be taken by the institutions are important to carry out the necessary studies on the collections and archives that are, at least, possible to be open for public use. 


\section{Giriş}

Mektup formu, modern edebiyat kamusunda kalem erbabına çeşitli diyalog imkânları sunması, müzakere ve etkileşim alanları açması bakımından hayli işlevsel bir araç olagelmiştir. Namık Kemal'in oldukça hacimli ciltleri dolduran yazışmaları, Fatma Aliye ile Ahmet Mithat Efendi arasındaki mektuplaşmalar, Abdülhak Hamid ve Recaizade Mahmut Ekrem arasında cereyan eden Nesteren konulu münakaşa ve daha pek çok örnek vakaya baktığımızda bilhassa modern edebiyatın teşekkül sürecinde yazarlar arasında canlı bir diyalog ve müzakere evreninin varlığ 1 göze çarpar. Diğer yandan, Okay’ın ifade ettiği gibi, belgesel hususiyetleriyle özel mektuplar, “dönemlerine, kişilere, kişiler arasındaki ilişkilere, sanat eserlerinin arka planındaki çok defa bilinmeyen oluşum safhalarına ışık tutan, dolayısıyla monografik/biyografik araştırmalarda önemli kaynaklardan birini teşkil etmektedir."' Bu makalede, ilgili bağlamlardan hareketle, Recaizade Mahmut Ekrem'in Sadullah Paşa'ya yazdığı, şu ana dek kaynaklarda yer almamış ve ilk defa burada yayımlanacak mektuplar edebiyat tarihi açısından incelenecektir. Nitekim Recaizade Mahmut Ekrem'in Sadullah Paşa’ya yazdı̆̆ı mektuplar, o dönem ve sonraları yaşanan pek çok gelişmenin arka planını ve ilgili şahısların edebî serüvenlerini daha yakından kavramak adına önemli veriler barındırmaktadır.

\section{Edebiyat Tarihinin Kayıp Figürü: Sadullah Paşa}

Daha çok “Ondokuzuncu Asır” manzumesi ile tanınan Sadullah Paşa, modernleşme dönemi Osmanlı edebiyat tarihinin hakkında en az malumat sahibi olduğumuz simalarından biridir. Namık Kemal ve arkadaşlarıyla aynı kuşağa mensup olarak değerlendirebileceğimiz Sadullah Paşa'nın pek az metni elimize ulaşmış durumdadır. ${ }^{2}$ Varlığından haberdar olduğumuz kimi eserlerinin akıbeti günümüzde hâlâ meçhuldür. Aile efradından Münevver Ayaşlı, hatıratında, intihar ${ }^{3}$ olayından sonra Sadullah Paşa' dan geriye kalan defterleri ve belgeleri toplu hâlde büyük bir sandık içerisinde, onun biyografisini yazması için Mithat Cemal Kuntay’a teslim ettiğini belirtir. Ayaşlı, Sadullah Paşa'ya ait tüm resmî ve hususi evrakın bu sandıkta olduğu bilgisini vermektedir. Ne var ki Kuntay herhangi bir çalışma yayımlamadan vefat etmiş, kendisine intikal eden sandık da içindeki defterler ve belgelerle birlikte kaybolmuştur. ${ }^{4}$ Kuntay da Sadullah Paşa'nın yayımlanmamış şiirlerinin kendisinde olduğunu teyit etmektedir. ${ }^{5}$ Öte yandan Hasan Âli Yücel, Sadullah Paşa'nın İlyada çevirisini Kuntay’da gördüğünü, on beyitlik bir bölümün manzum, 46-47 sayfalık bir bölümün de mensur olarak çevrilmiş olduğunu belirtir. Kuntay'dan

\footnotetext{
Orhan Okay, Batılılaşma Devri Türk Edebiyatı, (İstanbul: Dergâh Yayınları, 2011) 226.

Sadullah Paşa hakkında en kapsamlı biyografik çalışmayı hazırlayan Ali Akyıldız, ilgili eserinde onun edebî metinleri ile çok sayıda hususi mektubunu ve kaleme aldığı kimi diğer metinleri bir araya getirmiştir: Ali Akyıldız, Sürgün Sefir Sadullah Paşa, (İstanbul: Türkiye İş Bankası Kültür Yayınları, 2011) 247-396.

3 Sadullah Paşa, özel hayatında yaşadığı çalkantı sonucu 1891 yılı Ocak ayında intihara teşebbüs eder ve tüm çabalara rağmen kurtarılamaz. Ayrıntılar için bk. Akyıldız, Sürgün Sefir Sadullah Paşa.

4 Münevver Ayaşlı, Işsittiklerim, Gördüklerim, Bildiklerim, (İstanbul: Boğaziçi Yayınları, 1990) 145-150.

5 Akyıldı, Sürgün Sefir Sadullah Paşa, 211.
} 
izin alarak ilk on beyti istinsah eden Yücel, daha sonra bu küçük parçayı yayımlamıştır. ${ }^{6}$ Sadullah Paşa tarafından yapılan Türkçedeki ilk Homeros çevirisi de -on beyitlik istisna hariç- onun diğer eserleri gibi okurla buluşamadan kaybolmuştur. Çeşitli tanıklıklar ve ipuçları dolayısıyla varlığından haberdar olduğumuz, Sadullah Paşa'ya yazılmış kimi mektupların da aynı akıbete uğradığını düşünebiliriz. Dolayısıyla onun diyalog ve etkileşim alanı hakkındaki bilgilerimiz de birtakım bilgi kırıntıları ile sınırlı kalmıştı. Bugün, yeni elde ettiğimiz ve her iki ismin biyografileri, edebiyat anlayışları yanı sıra genel olarak edebiyat tarihi açısından da önemli belgeler niteliğindeki mektuplar aracılığıyla, Sadullah Paşa'nın Recaizade Mahmut Ekrem'le güçlü bir diyalog içerisinde olduğunu öğrenmiş bulunuyoruz.

Recaizade Mahmut Ekrem'in ona yazdığı mektuplardaki veriler Sadullah Paşa'nın günümüze yansıyan portresini bir parça daha aydınlatacak niteliktedir. Her ne kadar onun Recaizade Mahmut Ekrem'e cevaben yazdığı mektuplara ulaşılamamış olsa da hâlihazırdaki veriler her şeyden önce Sadullah Paşa'nın etki alanının tahmin edilenden daha geniş olduğunu kanıtlayacak niteliktedir. Ayrıca Recaizade'nin Sadullah Paşa'nın kendisine yazdığı mektuplardan yaptığı alıntılar da önemli ipuçları barındırmaktadır ki böylece Sadullah Paşa’nın kimi konulardaki kanaatleri hakkında bu yolla malumat sahibi olabiliyoruz. Söz konusu mektupların tam metinleri ve Recaizade'nin bu vesileyle yeni tespit edilen bir şiiri de makalenin ekler bölümünde yer almaktadır.

\section{Recaizade Mahmut Ekrem ve Sadullah Paşa Diyalogu Hakkında}

Sadullah Paşa'nın Berlin (1877-1883) ve Viyana (1883-1891) sefirliği esnasında sürdürülen mektuplaşmadaki samimi havadan anlaşıldığı üzere iki ismin daha önceleri kayda değer düzeyde bir tanışıklık veya dostlukları mevcuttur. Ebüzziya Tevfik'in, Sadullah Paşa'nın yanında Viyana Sefareti İkinci Kâtibi olarak görev yapan ve onunla şahsi görüşmelerinden hareketle Sadullah Paşa Yahut Mezardan Nida isimli eseri kaleme alan Mehmed Galip Bey’e yazdığı mektupta belirttiğine göre iki ismin tanışıklıkları 1868 yılına dek uzanmaktadır: "Bu tarihten iki sene sonra [1868'de] teşekkül eden Şûrâ-yı Devlet' in Maârif Dairesi ... cidden bir daire-i maârif idi. ... Sadullah Paşa, Başmuâvin; Dadyan Artin Efendi, Recaizade Ekrem Bey, Muâvin; bu abd-i âciz ile ... Mehmed Mansur Efendi ve ... Dragon Çangof Efendi birinci mülâzım idiler." $\mathrm{Bu}$ tarihlerde Recaizade henüz 21 yaşlarındadır. Recaizade'nin Sadullah Paşa'yı erken yaşlarda tanımış ve onunla çalışmış olması, aşağıda karşımıza çıkacak olan dostluk tablosunun ve etkileşimin boyutunu anlamlandırmamız açısından tamamlayıcı bir bilgidir.

Elimizdeki mektupları edebiyat tarihi açısından incelemeye geçmeden evvel, bunların nasıl ortaya çıktıkları ve kronolojileri hakkında genel bir değerlendirme yapmak da yararlı olacaktır. Bugüne dek saklı kalmış olan mektupların kaynakları ve şimdiye kadar neden tespit edilemedikleri kısaca şu şekilde açıklanabilir: Ali Akyıldız'ın ifade ettiği gibi, intihar

6 Hasan Âli Yücel, Edebiyat Tarihimizden, (İstanbul: İletişim Yayınları, 1989) 297.

7 Mehmed Galib Bey, Sadullah Paşa Yahud Mezardan Nidâ, haz. Nazir Akalın, (İstanbul: Dergâh Yayınları, 2003) 86. 
vakasının ardından Sadullah Paşa'nın Viyana'daki evrakı ve eşyası Sultan II. Abdülhamid'in talimatıyla Rıdvan Paşa başkanlığında kurulan soruşturma komisyonunun girişimi ve denetimi doğrultusunda İstanbul'a getirildi. Yapılan inceleme sonucu, bunların arasından devlet işlerini ilgilendirenler ile Sultan II. Abdülhamid'in ilgi duyabileceği belgeler seçilerek saraya (Yıldız) gönderildi. Geriye kalan özel evrak ise Sadullah Paşa'nın ailesine teslim edildi. ${ }^{8}$ Hâlihazırda ortaya çıkan fotoğraf itibariyle, aralarında hususi mektupların da bulunduğu, paşaya ait bir kısım evrakın Topkapı Sarayı'na intikal etmiş olduğu anlaşılmaktadır. Zira Recaizade Mahmut Ekrem' in Sadullah Paşa'ya yazdığı mektuplardan dört tanesi, 2017 yılında Devlet Arşivleri'ne devredilen Topkapı Sarayı Müzesi Arşivi Evrakı (TS.MA.e) içinde tespit edilmiştir. Bununla beraber yine Sadullah Paşa'nın oğlu Âsaf Bey ile özel yazışmalarının da burada yer aldığı görülmektedir. İlgili evrakın henüz son yıllarda Devlet Arşivleri Başkanlığı Osmanlı Arşivleri’ne aktarılmış ve tasnif edilmiş olması, Recaizade Mahmut Ekrem'in Sadullah Paşa'ya yazdığı mektupların bugüne dek neden ortaya çıkmadığını açıklamaktadır. Dışarıdan bakıldığında resmî nitelik taşımayan ve intihar soruşturması kapsamında da herhangi bir önem taşımadıkları açık olan bu mektupların neden diğer özel belgelerle birlikte Sadullah Paşa ailesine teslim edilmediği ise bir soru işaretidir. Üst düzey bürokratik görevlerde bulunan Recaizade Mahmut Ekrem'in Sadullah Paşa'yla ilişkisinin otoritelerin dikkatini çektiği için ilgili mektupların tetkik edilmek üzere ayrılıp aileye teslim edilmemiş olması akla ilk gelebilecek ihtimallerden biridir.

TS.MA.e bünyesinde tespit edilen dört mektup, Sadullah Paşa'nın Berlin Sefiri olarak görev yaptığı yıllarda Recaizade Mahmut Ekrem tarafından kendisine gönderilmiştir. Zarflardan anlaşıldığı üzere (bk. Ekler) Osmanlı Devleti'nin Berlin Sefaretine postalanan mektuplar, sırasıyla şu tarihlerde kaleme alınmıştır: 27 Eylül 1877, 10 Aralık 1877, 17 Haziran 1879, 7 Ağustos 1879. Bu çalışmaya konu olan 13 Haziran 1884 tarihli beşinci mektup ise İstanbul Şehir Üniversitesi bünyesinde yer alan Taha Toros Arşivi'nde tespit edildi. ${ }^{9}$ İlgili mektup, Taha Toros Arşivi'nde muhatabı tespit edilememiş biçimde "Recaizade Mahmud Ekrem tarafından Viyana'da resmî bir kuruma gönderilen mektup" bilgisi ile kataloglanmıştı. Ancak dikkatle incelendiğinde mektubun tam da Sadullah Paşa'nın Viyana sefiri olarak görev yaptığı dönemde (13 Haziran 1884'te) kaleme alınmış olması, ikilinin devamlı olarak mektuplaşmaları ve ayrıca Recaizade Mahmut Ekrem'in Sadullah Paşa'ya gönderdiği diğer mektuplarında olduğu gibi kendisinden üst mertebede yer alan bir devlet büyüğüne yazar şekilde "Mekârim-perdâz asdikâ-nüvâz devletlü efendimiz hazretleri" hitabiyla mektuba kitabet teamüllerine uygun bir giriş yapması, Recaizade Mahmut Ekrem'in imzasını taşıyan bu mektubun da Sadullah Paşa'ya yazıldığını ispatlamaktadır. Hem tarihlerden hem de mektuplardaki ifadelerden çıkarılacağı üzere ikili arasında zamana yayılmış devamlı bir diyalog ve müzakere söz konusudur. Lakin Sadullah Paşa'nın Recaizade Mahmut Ekrem'e yazdığı mektuplar henüz tespit edilememiştir.

Söz konusu beş mektubun muhtevasına genel olarak baktığımızda ana gündem maddesinin

8 Akyıldız, Sürgün Sefir Sadullah Paşa, XV.

9 “Recaizade Mahmud Ekrem tarafından Viyana'da resmi bir kuruma gönderilen mektup”, İstanbul Şehir Üniversitesi Taha Toros Arşivi, Erişim: 01.06.2020 http://earsiv.sehir.edu.tr:8080/xmlui/handle/11498/19805 
o yılların güncel edebiyat meseleleri olduğunu görüyoruz. Sadece 27 Eylül 1877 tarihli mektup bu parantezin dışındadır. Diğerlerine kıyasla daha kısadır ve herhangi bir özgül konudan bahsedilmemektedir. 93 Harbi olarak bilinen 1877-1878 Osmanlı-Rus savaşının yaşandığı sıkıntılı günlerde kaleme alınan mektupta Sadullah Paşa'nın sefaret görevini devralmak üzere gittiği Berlin'de üst düzey bir protokolle karşılanmasından duyulan sevinç dile getirilmekte ve yaklaşan Ramazan Bayramı tebrik edilmektedir. Diğer mektupların muhtevası ise aşağıda ayrıntılı olarak değerlendirilecektir.

19. asır Osmanlı kültür ve sanat tarihinde öne çıkan söz konusu iki isim arasında tespit edilen yazışmanın edebiyat tarihi açısından en önemli hususiyetlerinden biri, eserleri ve evrakı kayıp olduğundan hakkındaki malumatımız sınırlı olan Sadullah Paşa'nın etkileşim alanı hakkında yeni bilgilere sahip olmamızı sağlayacak veriler içermesidir. Bugüne kadarki tanıklıklardan, paşanın modernleşme döneminde etkili ve muteber bir figür olduğu anlaşılmaktadır. Söz gelimi Abdülhak Hâmid, hatıratında “...esâlib-i muhtelifede ifade-i hal, yahut idare-i makal ve belki de icâle-i fikr ü hayal edişimin mesul ve müsebbiblerini sırasıyla söyleyeceğim”" diyerek kendisinin edebî anlamda gelişiminde katkısı ve tesiri olan kimseleri zikrettiği uzun liste içerisinde Sadullah Paşa'ya ilk sıralarda yer verir. ${ }^{10}$ Ahmet Mithat Efendi ise Stockholm'de düzenlenen Şarkiyatçılar Kongresi'ne (1889) katılmak üzere çıktığı seyahat esnasında Viyana'da görüştüğü Sadullah Paşa ile gerçekleştirdiği sohbetten bahsederken "buyurdukları mülahazatı o kadar doğru buluyordum ki zaten irfan ve hikmetle müştehir olan o büyük adam” şeklindeki nitelemeleriyle kendisinden hayranlıkla bahseder ve paşanın dönemindeki şöhretine dair ipuçları sunar. ${ }^{11}$ Kendi kuşağından Namık Kemal'in de bir mektubunda Sadullah Paşa'dan övgüyle bahsettiği bilinmektedir. ${ }^{12}$

Mektuplardaki veriler ve Talim-i Edebiyat'taki verileri tarihsel arka planları ile birlikte değerlendirdiğimizde ise Sadullah Paşa'nın Recaizade Mahmut Ekrem'in edebiyat dünyasında da oldukça etkili bir isim olduğu sonucuna ulaşıyoruz. Genel olarak baktığımızda ona duyduğu hayranlık ve hürmeti yazışmalarında sıkça vurgulayan Recaizade Mahmut Ekrem, bilhassa 7 Ağustos 1879 tarihli mektubundaki şu satırlarda Sadullah Paşa'nın üslubuna hayranlığını ve mektuplaşmalarından duyduğu mutluluğu tumturaklı ifadelerle dile getirir:

Efendimize daima arîzalar takdim edeyim, cümlesinin cevaplarına nâil olayım diyorum. Bir arîza takdim edince cevabını pek tatlı bir intizar ile bekliyorum. İhsannâme-i devletlerini alınca defaatle okuyorum, saatlerce elimden bırakamıyorum. F1karât-1 bende-perverânesinden o kadar kesb-i sürur ediyorum ki tavsifi nâ-kâbil. Mündericât-1 edebiyyesinden o derece lezzetyâb oluyorum ki tarifi müstahildir. İşte bu defaki keremnâmelerini dahi o vechile telakki eyledim. Fehâvâ-yı latîfesi emsaline fâik, mezâyâ-yı edebiyyesine lübb-i hikmet ve hakikat denilse lâyıktır.

10 İnci Enginün, Abdülhak Hâmid' in Hatıralarl, (İstanbul: Dergâh Yayınları, 1994) 48.

11 Ahmet Mithat Efendi, Avrupa'da Bir Cevelan, haz., N. Arzu Pala, (İstanbul: Dergâh Yayınları, 2015) 999.

12 Fevziye Abdullah Tansel, Namık Kemal' 'in Hususi Mektuplart: İstanbul Avrupa ve Magosa Mektupları, (Ankara: Türk Tarih Kurum, 1967) 348. 
İlk bakışta bu ve diğer mektuplardaki birtakım ifadelerin kişisel yazışmalardaki nezaket gereği söylenmiş sözler olarak yorumlanması gerektiği ileri sürülebilir. Ancak örneklem oluşturma stratejisi dolayısıyla edebiyat tarihinin en büyük münakaşalarından birine konu olmuş Talim-i Edebiyat'a baktığımızda, ilgili ifadelerin oldukça gerçekçi bir zemine dayandığı kanaati hasıl olacaktır. Şöyle ki Recaizade Mahmut Ekrem'in Mekteb-i Mülkiye'de verdiği derslerin notlarından hareketle hazırladığı ve kurulmak istenen modern edebiyat geleneğinin ilk ve önemli kuramsal eserlerinden biri olarak tarihteki yerini alan Talim-i Edebiyat, yayımlandıktan sonra klasik edebiyat taraftarlarınca farklı gerekçeler doğrultusunda sert eleştirilere uğramıştı. Kâzım Yetiş'in bu eser üzerine yaptığı kapsamlı çalışmasında ortaya koyduğu gibi Recaizade'nin eleştirildiği noktalardan bir tanesi de ilgili bahislerde olumlanıp doğru kullanım timsali olarak sunulan edebî metin parçalarının ekseriyetle modern edebiyattan; olumsuzlanan, zayıf ve menfi olarak örnek gösterilen parçaların ise klasik edebiyattan seçilmiş olmasıdır. ${ }^{13}$ Nitekim Yetiş'in sunduğu istatistiksel verilere bakıldığında ${ }^{14}$ muarızlarının Recaizade'ye yönelttikleri bu eleştiri noktasında pek de haksız sayılmadıkları söylenebilir. Klasik edebiyattan seçilen metin örnekleri çoğunlukla negatif yönleri ile okura takdim edilirken modern edebiyattan seçilenler ise pozitif yönleriyle ön plana çıkarılmaktaydı. Bu noktadan bakıldığında, kanaatimce Recaizade'nin göstermiş olduğu refleks, o günler itibariyle henüz teşekkül etmekte olan modern edebiyat geleneğinin kanonlaştırılmasına yönelik bir girişim olarak değerlendirilmelidir. Recaizade'nin kendisini modern edebiyat kamusu içerisinde konumlandırdığı göz önüne alınırsa, bu şekilde öznel bir tutum sergilemesinin nedeni daha iyi anlaşılacaktır. Zira söz konusu dönemde klasik edebiyat çizgisi kanonik gücünü hâlâ korumaktaydı ve buna mukabil edebî modernliğin temsilcileri kendi alanlarını inşa etmeye çalışıyordu. Bu bağlamda Talim-i Edebiyat'ta Sadullah Paşa'dan üç metin parçası çeşitli alt başlıklarda örnek olarak kullanılmıştır ki paşanın o gün itibariyle yayımlanmış çok az metni olduğunu hesaba katarsak bu sayı daha da dikkat çekici bir veri olacaktır. Seçilen birinci örnek kitabın “Tabiiyyet” konusu içindir. Sadullah Paşa'nın, kardeşi Said Bey’e yazdığı mektuptan bir parça tabiiyyete, doğallığa misal verildikten sonra şöyle bir yorum yapılır:

İşte bu mektubun ne elfâzına o kadar sade diyebiliriz ne de mevzuunun ehemmiyeti inkâr olunabilir. Fakat yazış o kadar tabiî ve binaenaleyh o derece güzeldir ki ve bilhusus tabiiyyet mevzuundaki müeessirliği tarz-1 ifadesi[n] o kadar nazikleştirmiştir ki her kime okunsa anlar, mürseliyle mürselün-ileyhinin teessürâtına tabiî iştirak eder.

Güya ki müellifi kalemi eline aldığı zaman ne yazacağını nasıl yazacağını düşünmeyerek âyine-i vicdanına atf-1 nazarla hakikat ve tabiiyyetten oraya in'itaf eden nakş u nigâr-1 maânînin kâğıt üzerine nakl ve tersimini maharet-i kalemine havale etmiş ve o suretle yazmış! ${ }^{15}$

13 Talim-i Edebiyat etrafında yaşanan münakaşalar hakkında tafsilatlı bilgi için: Kâzım Yetiş, Talim-i Edebiyat'ın Retorik ve Edebiyat Nazariyatı Sahasında Getirdiği Yenilikler, (Ankara: Atatürk Kültür Merkezi, 1996) 323-504.

14 Yetiş, Talim-i Edebiyat'ın Retorik ve Edebiyat Nazariyatı Sahasında Getirdiği Yenilikler, 251.

15 Recaizade Mahmut Ekrem, Talim-i Edebiyat, (İstanbul: Mihran Matbaası: 1299 [1882]) 159 - 160. 
Sadullah Paşa'nın kardeşine yazmış olduğu özel bir mektuptan bir parçanın alınmış olması başlı başına dikkat çekici bir durumdur. Nitekim Recaizade Mahmut Ekrem'in Sadullah Paşa'ya yazdığı 17 Haziran 1879 tarihli mektupta, "Bazı zevâta yazılmış mekâtîb-i edîbânelerinin evsâfını işittiğim halde hiçbirisini ele geçirmek kâbil olamadı.” diyerek onun birtakım isimlerle yazışmalarından haberdar olduğunu belirttiği, fakat "âsâr-1 nefîse meraklıları ... ellerine geçen nevâdir-i edebiyyeyi nakd-i hasis gibi çekmecelerde hapse[ttikleri]" için bunlara ulaşamadığına hayıflandığg görülüyor. Bu beyanlardan, hem Recaizade'nin Sadullah Paşa'nın metinlerine ve görüşlerine yönelik ilgisine, hem de genel olarak mektup türü yazıların döneminde birer edebî metin mesâbesinde değerlendirilebildiğine dair fikir edinebiliyoruz.

Talim-i Edebiyat'ta Sadullah Paşa'dan ikinci alıntı, "Üslub-1 Müzeyyen” alt başlığında yapılır. Recaizade, üslub-1 müzeyyeni ana hatlarıyla şöyle tarif eder: "Üslub-1 sade" sulu boya tablo ise "üslub-1 müzeyyen" yağlı boya tablodur. Üslub-1 müzeyyen, üslub-1 sade ile üslub-1 âlînin arasında olmakla beraber, ziynet ve letafet bakımından birincisinin üstünde, şiddet ve ulviyet bakımından ise ikincisinin altındadır. "Tabiatinde itidal ve halâvet bulunan her tür nevi efkâr ve hissiyât ve teessürâtın tercüman-1 beliği” olarak ifade ettiği üslub-1 müzeyyenin özellikle şairâne tasvirlere yakıştığını söyler. Bu açıklamaların akabinde Namık Kemal'in “Gelibolu”su ile Sadullah Paşa'nın "Charlottenburg Sarayı" başlıklı yazılarından birer parçayı üslub-1 müzeyyenin mensur örnekleri olarak okura sunar. ${ }^{16}$ Üçüncü alıntıyı ise çok önemli olduklarını vurguladığı teşhis ve intak adlı söz sanatlarına ayırdığı kısımda yapar. Ona göre, “Teşhis ve intak dehanın kaleminden sâdır olduğu zaman gayet ulvi gayet müessir olursa da bî-kudret olan erbab-1 kalemin isti'mal etmesi hâlinde gülünç olmaya pek müstaiddir."17 $\mathrm{Bu}$ açıklamadan sonra teşhis ve intak sanatlarına Osmanlı edebiyatından tek mensur metin örneğini Sadullah Paşa'nın “1878 Paris Ekspozisyonu” başlıklı yazısından verir. ${ }^{18}$ Bütün bu tablo, Recaizade Mahmut Ekrem'in Talim-i Edebiyat'taki örneklem oluşturma stratejisi ve yorumları ile bir arada değerlendirildiğinde, Sadullah Paşa onun için edebî modernleşme sürecinde kanonik bir isimdir. Nitekim aşağıda da görüleceği üzere Recaizade Mahmut Ekrem, kalem erbabının nasıl yazı yazılacağını Sadullah Paşa gibi isimler sayesinde öğrendiklerini belirtecek ve bu noktada paşa, bir inkılapçı olarak nitelenecektir.

İkili arasındaki diyalogun önemli taraflarından biri de kalem mesaileri hakkında birbirleriyle paylaşımda bulunuyor olmalarıdır ki bu sayede Recaizade Mahmut Ekrem'in kitaplarına girmeyen ve günümüze intikal etmediği anlaşılan bir şiirine de ulaşmış bulunuyoruz. 10 Aralık 1877 tarihli mektupta, "Hal ve mevki müsait olmadığı halde mücerred biraderim bendelerinin teşviki üzerine mumâileyhe nazire olarak inşad ettiğim manzumelerden iki kıtası belki bir aralık tenezzüh-i efkâr-1 âlîlerine medar olur mütalaasıyla leffen takdim olundu." notuyla gazel formundaki iki şiir Berlin sefirine gönderilmiştir. Şiirlerin yer aldığı ek sayfasının sonunda ise şu not yer almaktadır: "Evvelkinin ekser-i ebyâtı yeni, diğeri ise tamâmiyle eski fikre tâbidir." Bu iki gazelden "göster"

16 Recaizade Mahmut Ekrem, Talim-i Edebiyat, 200-201.

17 Recaizade Mahmut Ekrem, Talim-i Edebiyat, 287.

18 Recaizade Mahmut Ekrem, Talim-i Edebiyat, 288. 
redifli olanı, ikinci beytin ikinci mısraı değiştirilerek Zemzeme I'e alınmıştır. ${ }^{19}$ "Kâbildir" redifli gazel (bk. Ekler) ise Recaizade'nin sağlığında yayımlanan şiir kitaplarında yer almadığı gibi, sonraki yıllarda dergilerde kalmış bazı şiirlerinin eklenmesiyle hazırlanan Latin harfli edisyonlarda da bulunmamaktadır. Tespit edebildiğim kadarıyla bu gazel yayımlanmamıştır ve ilk defa burada okurlara ulaşacaktır. ${ }^{20}$ Recaizade'nin ifadelerinde dikkat çeken noktalardan biri de söz konusu şiirleri tanziren kaleme almış olmasıdır. Açık şekilde isim vermese de "mücerred biraderim" ifadesi, şairin ağabeyi Recaizade Mehmet Celal'i (1838-1882) akla getirmektedir. İbnülemin M. Kemal İnal, Mehmet Celal'in Encümen-i Şuarâ üyelerinden olduğunu kaydeder. İnal'ın verdiği diğer bilgilere göre Mehmet Celal'in şiirleri basılmamıştı ve kardeşi Recaizade Mahmut Ekrem'de saklı bulunmaktayd $1 .{ }^{21}$ Dolayısıyla bu şiirin Recaizade Mehmet Celal'e nazire olarak yazılmış olması kuvvetle muhtemeldir. Öte yandan "Kâbildir" redifli gazeldeki, "Vücûb-1 vahdete her şeyle istişhâd kâbildir / Ene'l-hakk'1 ana bürhan gibi îrâd kâbildir” beyti, Şinasi'nin kendinden çokça söz ettiren "Münacaat"ındaki "Vahdet-i zâtına aklımca şahadet lazım” mısraı ile "Kimi sâbit kimi seyyar be-takdir-i Kadîr / Tanrı'nın varlığına her biri bürhan-1 münir"22 beytini anımsatır niteliktedir: Bu bağlamda Recaizade'nin mektubunda, söz konusu gazeli “yeni fikirlerle" yazdığına dair düştüğü notu da tekrar hatırlamakta fayda vardır.

Recaizade'nin yazdığı 1879 tarihli şu satırlar da ikili arasındaki alışverişten öte o dönemin kalemleri arasındaki etkileşime dair fikir vermekle beraber Sadullah Paşa'nın kayıp çalışmaları hakkında da ipucu niteliğindedir: "Elde başlanmış bazı şeyler olduğundan bahis buyruluyor. İnşallah ikmâl buyrulduğunda kulunuza ihsan buyrulursa ba'de'l-istinsah asıllarını yine efendimize iade eder ve müsaade buyrulursa teksir-i nüsahı için isteyenlere dahi veririm." Bu ifadeler, modernleşme dönemi Osmanlı edebiyat kamusu içerisinde, telif edilen eserlerin sadece basım ve yayın yoluyla değil aynı zamanda kişisel iletişim yollarıyla da dolaşıma girdiğine dair bir emare niteliğindedir. Yazışmaların tamamına henüz ulaşılamadığı için Sadullah Paşa'nın eserlerini veya müsvedde parçaları Recaizade’ye gönderip göndermediğini ise bilmiyoruz.

\section{Mektuplaşmadaki Edebiyat Gündemi}

Recaizade Mahmut Ekrem, Sadullah Paşa ile aralarındaki mektuplaşmayı, "Hususiyle teâtî-i efkâr-1 edebiyye ile gayet vâsi, gayet feyizli bir zeminde şekl-i dîger alan" "23 bir yazışma olarak nitelemektedir. Dostâne bir kişisel iletişim zemininde başlayan "mükâtebe", zamanla

19 İlgili mısra mektupta "Tebhâleden yüzünde şekl-i habâb göster” biçiminde karşımıza çıkarken Zemzeme'de "Tebhâleden de onda şekl-i hicâb göster" olarak yer almaktadır. Bk. Recâizade Mahmut Ekrem, Şiirler, haz. Hakan Sazyek, Esra Sazyek, Betül Solmaz, (Kocaeli: Umuttepe Yayınları, 2019) 176.

20 Ancak bu şiirin yayımlanıp bir dergi nüshasının sayfaları arasında unutulmuş ve sonradan tespit edilememiş olması sebebiyle bahsi geçen kitaplarda yer almamış olması da ihtimal dâhilindedir. Bir diğer ihtimal ise müstear imzayla yayımlanmış olmasıdır. Nitekim Recaizade’nin bu denli önemsediği bir isme, değerlendirmesi amacıyla sunduğu az sayıdaki şiirden birini yayımlamış olması da güçlü bir ihtimaldir.

21 İbnülemin Mahmut Kemal İnal, Son Asır Türk Şairleri, C. I (İstanbul: Milli Eğitim Basımevi, 1969) $198-199$.

22 İbrahim Şinasi Efendi, "Münacaat", Yeni Türk Edebiyatı Metinleri 1: Şiir, haz. İnci Enginün, Zeynep Kerman (İstanbul: Dergâh Yayınları, 2011) 84-85.

23 Bk. Ek 4. 
edebiyat üzerine fikir alışverişlerinin aracına dönüşmüştür. Nitekim mektuplaşmaya genel hatlarıyla baktığımızda ikilinin yeni bir edebiyat geleneği inşa etme bağlamında modernleşme süreciyle tezahür eden kimi meseleler hakkında müzakerelerde bulunduklarını görüyoruz. $\mathrm{Bu}$ çerçevede öne çıkan temaları şu başlıklar altında değerlendirebiliriz:

\section{a. Milli Edebiyat Tartışmalarının Ayak Sesleri: "Hâssa-i Kavmiyye"}

Bilhassa 1879 y1lına ait mektuplarda öne çıkan gündem maddesi “edebiyatta terakki”dir. 19. asır ve sonrasının anlam bagajı hayli yüklü karakteristik kavramlarından "terakki”, edebiyat kamusundaki tartışmalarda da anahtar kelimelerden biriydi. Burada edebiyatın terakkisinden maksat, anlaşılacağı üzere, Batı'da serpilen modern edebiyat örnekliğinde yeni bir edebiyat anlayışının inşa edilmesidir. Böyle bir önerme, zımnen de olsa elbette bir "geri kalma”, birtakım ilerlemelere ayak uyduramama iddiasını içermektedir. Bu nokta itibariyle, her iki isim de ilerleme yolunda yaşanan gecikmeyi kimi etkenler doğrultusunda gerekçelendirir. Aşağıda görüleceği üzere Talim-i Edebiyat yazarı, geride kalmışlı̆̆ daha ziyade şiir estetiği ve edebiyat eleştirisi bağlamında yorumlayacaktır. Sadullah Paşa ise o günlerin aktörlerinden duymaya pek de alışık olmadığımız, daha çok Meşrutiyet ve Cumhuriyet sonrasında karşımıza çıkacak bir argümanla görüşlerini temellendirir: Ona göre, Türk boyları medeniyet yoluna girdikleri dönemlerde Arap ve Acem şairleri taklit ederek Türk edebiyatının gelişmesini sağlamışlardı. Ancak devrim niteliğindeki bu hamleyi gerçekleştirirken, Türk şiirinin "hâssa-i kavmiyye”sini muhafaza edememişlerdir. Sadullah Paşa kuşağından Namık Kemal ile Ziya Paşa gibi isimler de klasik Osmanlı edebiyatını Arap ve Acem edebiyatlarıyla olan iltisakı dolayımında üst perdeden sert dille eleştirmişti. Fakat onlar daha ziyade şiir estetiği ve gerçeklik anlayışı açısından konuyu ele almıştı. Sadullah Paşa'nın serdettiği fikirler ise 20. asrın eşiğinde filizlenecek milliyetçi eleştirinin önermelerini hatırlatacak niteliktedir ve onların bir öncülü olarak değerlendirilebilir. Meşrutiyet ve Cumhuriyet günlerinde klasik Osmanlı edebiyatına yöneltilecek başlıca eleştirilerden biri de onun milli bir edebiyattan ziyade kozmopolit bir edebiyat olduğuydu. Sadullah Paşa'nın mektubunun tamamı elimizde olmadığı için bazı yönlerden ihtiyat payı bırakmakta yarar var. Ancak her hâlükârda, 1879 yılı bu tartışmalar için erken diyebileceğimiz bir tarihtir. Diğer yandan Recaizade'nin de Sadullah Paşa'nın önermesini “mübâhasât-1 edebiyyede zuhûra gelen ihtilâfât-1 kesîrenin birçoğunu def' ve izâle edecek bir keşf-i müdakkıkâne” olarak değerlendirdiği ve teyit ettiği görülüyor. Recaizade’ye göre eğer "hâssa-i kavmiyye" korunmuş olsaydı "terakki" sağlanacak ve "asrî” gelişmelere kendiliğinden ayak uydurulmuş olacaktı: "Şüphe yoktur ki edebiyatımız ibtidâdan kavmiyyetini muhafaza edeydi bugünkü terakkiyâtı kendi dâiresi içinde efkâr-1 asriyyeye tâbi olup gitmekten ibaret olurdu."

\section{b. "Muâheze" ve "Tetebbu" Noksanlığı}

Recaizade Mahmut Ekrem'in Sadullah Paşa'ya yazdığına göre “edebiyatta terakki” sağlanamamasının sebeplerinden biri de Osmanlı kültür dünyasında eleştiri (critique) geleneğinin 
yokluğudur. Bunu ifade ederken o dönem yaygın olan “takriz” uygulamasından, kendi ifadesiyle, “takriz dilenciliğì”nden duyduğu rahatsızlığı da dile getirir. Ona göre bir eser, eğer kendisi başarılı ve kıymetli değilse, "birkaç kişinin birer sebep veya mecburiyetle senâ-hânlık etmesi ona bir meziyet ilave edemeyeceği gibi zaten makbul olan bir eser umum nazarında kesb-i itibar etmek için her tür takrizâtdan müstağnidir.” Bu sözler, Recaizade'nin külliyatı dikkate alındığında daha bir ilgi çekici hâl almaktadır. Zira bilindiği üzere başkalarının (bilhassa öğrencilerinin) eserlerine çokça takriz yazan isimlerden biri de Recaizade'nin kendisidir. Bu satırları kaleme aldıktan sonra bizzat kendisi birtakım eserlere takrizler yazacak, daha önemlisi, sonraki yıllarda bunları bir araya getirip Takrizât isimli müstakil bir kitapta toplayacaktır. Tabii burada kendisinin yazmış olduğu takrizlerde "senâ-hânlık"la yetinmediğini ve yer yer eleştirel bir tutum sergilediğini de göz önüne almak gerekir. ${ }^{24}$ Recaizade, netice itibariyle, Osmanlı edebiyat kamusu içerisinde bir eleştiri geleneğinin acilen teşekkül etmesi gerektiğini savunur. Fransızca critique littéraire (edebî eleştiri) kavramı için de o günlerde kullanılmakta olan "muâheze-i edebiyye" tabirinin uygun olduğunu ve başka bir karşılık aramaya gerek olmadığını not düşer.

Recaizade için edebiyatta ilerlemenin bir diğer şartı da geçmiş edebiyat birikimi üzerine yapılacak araştırma ve incelemelere bağlıdır. "[E]debiyatın terakkisine hâdim olacak erbâb-1 isti' dâd ve kabiliyetin perveriş-yâb-1 kemâl olmaları kendilerinden evvel gelen üdebânın âsâr-1 kalemiyyesini tetebbu sayesinde" olacaktır. Nitekim kendisi de bu satırları yazdığı 1879'da Talim-i Edebiyat'1, bir süre sonra da Kudemâdan Birkaç Şair'i neşredecektir.

\section{c. Şiir Dili ve Vezin}

Recaizade'nin modern edebiyatın inşası konusunda öne sürdüğü düşüncelerde en çok vurgu yaptığı hususlardan biri de şiir dilindeki gelişmelerin nesir dilindeki gelişmelerden geri kalmış olmasıdır. 7 Ağustos 1879 tarihli mektupta, "Filhakika bugünkü tarz-ı inşâmızla efkâr ve âdâtın müsait olduğu derecede bir güzel roman yazılabilir. Lâkin fâilâtün mefâilün yolunda eğri büğrü ifâdât ve lisanımızın tabiatine gayetle mugâyir olan imâlât ve sâir birçok tekellüfât ile manzum bir tiyatro meydana konulamaz, konulsa da makbul olamaz." şeklinde dikkat çekici bir çıkarımda bulunan Recaizade'ye göre şiir dilindeki en önemli problem ise aruz vezninin Türkçenin doğasına aykırı olmasıdır. Aşağıda detaylandırılacağı üzere bu zorluğu aşmak için hece veznine geçişi savunacaktır. Şiir dili konusunda Sadullah Paşa ise Recaizade'nin aktarımına göre, Batılı yazarların şiirimizde benzeri olmayan eserlerini taklit etmek ve örnek almak gerektiğini, bu şekilde ilerleme sağlanacağını öne sürmüştür: "Bu yolda edilebilecek tecrübe-i sahîha üdebâ-yı garbın eş'ârımızda nazîri olmayan âsâr-1 nazmiyyesini tanzir ve taklit etmektir."

Recaizade Mahmut Ekrem'in mektuplarından birinde (17 Haziran 1879) dile getirdiği kimi görüşleri, onun kalem mesaisindeki sancılı tecrübelerden biri hakkında daha yakından malumat sahibi olmamızı sağlayacak ve ilgili sürecin arka planını içeriden kavramamıza

24 Recaizade Mahmut Ekrem, Takrizat, (İstanbul: yy., 1314.) 
yardımcı olacak niteliktedir. Şiir üzerine kafa yorduğu anlaşılan bir dönemde Sadullah Paşa ile paylaştığı vezin konusundaki iddialarıyla kısa zaman sonra bizzat yüzleşecek ve pratikte pek de istediği gibi bir sonuç alamayacaktır.

19. asrın ikinci yarısından 1930'lu yıllara dek edebiyat kamusunu meşgul edecek biçimsel problematiklerden biri de şiirde kullanılacak vezindi. Bilindiği üzere klasik Osmanlı şiirindeki vezin tercihi aruzdan yanaydı. Modernleşme süreci ile birlikte klasik Osmanlı edebiyatına karşı başlayan sorgulamalardan bu tercih de nasibini alacak, hatta yer yer gerilimin had safhaya ulaştığı münakaşalar yaşanacaktır. 17 Haziran 1879 tarihli mektubunda vezin meselesine tafsilatlı olarak temas eden Recaizade, bu konudaki fikirlerini başka hiçbir yerde olmadığ kadar kesin bir dille ifade eder: "Bazı efkâra göre evzân-1 Arabiyyeyi terk ile yerine bizim kahve şairlerinin kullandıkları parmak hesabını kabul etmeli imiş. Fikr-i âcizânem de böyledir." diyerek hece vezninden yana olduğunu dile getirir. Ona göre, Osmanlı şairlerini "tumturak-1 elfaz" merakına sürükleyen, hatta denilebilir ki bu yönde zorlayan şey aruz vezninin doğasıdır. Çünkü aruz vezni ile "lisan-ı Osman̂̂”nin şivesi uyuşmamaktadır. Eğer aruz terk edilip de yerine "parmak hesabı" yani hece vezni kullanılmaya başlanırsa zincirleme tamlamalarla ortaya çıkan "gayr-1 me’nûs kelimeler” kullanımı gibi kötülüklere de meydan verilmemiş olacağı gibi fesahat ve belâgat açısından anlam güzelliği ile anlam inceliği de sağlanacaktır. Bu argümanları sunan Recaizade, netice olarak, şiirde arzulanan "şahrâh-1 cedid-i terakki"nin açılabilmesi için heceye geçilmesi gerektiğini ileri sürer. Bu konuda tavrı çok nettir; şiirde yeni bir yol açılması, yeni bir atılım yapılması vezin konusundaki tercihe bağlıdır. Sözlerinin devamında da yazar ismi belirtmeden, o günlerde yeni edebiyat taraftarlarından birinin hece vezni ile telif ettiği bir tiyatro eserinden dört mısrayı "tabiî şiir heveskârları için numûme-i imtisal" olarak gösterir. Ne var ki Recaizade Mahmut Ekrem bu iddialarını dile getirdikten kısa zaman sonra hece veznini kullanmak istediği bir tercüme girişiminde başarısız olduğunu itiraf edecektir. Gıpta ile bahsettiği La Fontaine'den manzum tercümeler yapmaya başlayan Recaizade, her ne kadar kendisine daha geniş imkânlar sunacağını düşünüp parmak sayarak hece veznini kullanmaya teşebbüs etse de başarılı olamadığını beyan eder. "Ağustos Böceği ile Karınca” hikâyesini 11'li hece vezniyle tercüme edip Şemruh-ı Edeb'de neşrettiğini söyleyen şair, La Fontaine'den yaptı̆̆ 1 tercümeler için yazdı̆̆ 1 , 1881 'de Hazîne-i Evrak'ta yayımlayıp daha sonra Naçiz'e aldığı "Mukaddime"de heceye neden yöneldiğini ve sonra neden ondan vazgeçtiğini şu şekilde izah eder:

Herkes bilirim ki şair olmaz

Her fikri beyana kâdir olmaz

Tevfik ile hem sözü usule

Mef'ûl ü mefâil ü fuûle

Mümkün mü o sadelik o îcâz

O1 sâde-dilâne tavr-1 ser-bâz 
Tasvirinde o mümtezic-i renk

Âbın akışı gibi o âhenk

Bir şiir ki olmaya tabiî

Ben neylerim olsa da bediî

Efsanedeki o kıyl ü kâle

Hiç yakışır mı med - imâle

Türkî kelimât içinde medler

Olmaz mı sımâha nefret-âver

Aldım ele bi'z-zarûre hâme

Vermek diledim düzen kelâma

Güya daha vâsi' olduğundan

Âsân-ter olur gibi edip zan

Tanzimde saydım önce parmak

Amma yine olmadım muvaffak

Gördüm ki bu gelmiyor hesaba

Şâyân olmayacak intihâba

Nâçâr arûza ric'at ettim

Ehven görünen tarîke gittim. ${ }^{25}$

Recaizade'nin hece vezniyle birtakım şiir denemeleri olsa da La Fontaine tercümelerindeki tecrübesinden olsa gerek sonraları aruzla yola devam ettiği görülür. Sadullah Paşa'ya yazdığı mektuptan 1879 yılında hece vezninden çok emin olduğunu öğrendiğimiz Recaizade, kısa süre sonra bu iddiasından geri çekilecektir.

\section{d. Edebiyat Kavramının Görünümleri}

Edebiyat kavramının ne zamandan beri bugünkü anlamıyla kullanıldığına dair araştırmaların kesin bir sonuç verdiğini söylemek henüz mümkün görünmemektedir. Kaya Bilgegil, Orhan Okay ve Kâzım Yetiş gibi isimler başta olmak üzere bu alanda görüş bildirmiş araştırmacılar arasında yaygın kanaat, terim olarak “edebiyat"1n Türkçede 19. asrın ikinci yarısından itibaren

25 Recaizade Mahmut Ekrem, "Mukaddime”, Hazîne-i Evrak, 1, (1 Mayıs 1297 [13 Mayıs 1881]) 10-12; Recaizade Mahmut Ekrem, Nâçiz, (İstanbul: Mahmud Bey Matbaası, 1302) 76-79. "Mukaddime” ilk olarak Hazine-i Evrak'ta yayımlanmıştı. Ancak Hazîne-i Evrak'taki dizgi hataları sebebiyle "Mukaddime"den alıntılar Nâçiz'deki metinle karşılaştırılarak yapıldı. 
günümüzdeki anlamıyla kullanılmaya ve yerleşiklik kazanmaya başladığıdır. ${ }^{26}$ Okay, kelimenin 1860'tan sonra Fransızca "littérature" veya "belles-lettres" kavramlarını karşılamak üzere, tıpkı bu dönemde ortaya çıkan lisaniyat, arziyat, ruhiyat terimleri ile aynı kalıp ve mantıkla türetildiğini ifade eder. Daha öncesinde ise Ziya Paşa'nın meşhur yazısında karşımıza çıktığı gibi şiir ve inşâ tabirleri nazım ve nesri tanımlamak üzere ayrı ayrı kullanılmaktaydı. Bugünkü gibi hepsini kuşatan bir edebiyat kavramı yürürlükte değildi. Bilgegil ise, "Çok eski çağlarda 'dâvet' mânâsına gelen 'edb'; İslâmlıktan bir yüz yıl önce, zariflik ve ahlâkla ilgili 'edeb' kelimesini doğurmuştu." ${ }^{27}$ dedikten sonra bu durumun Emevilerin son, Abbasilerin ilk yıllarına kadar sürdüğünü belirtir. Daha sonra, Emevilerin son yıllarını ve Abbasilerin ilk yıllarını kapsayan tarihsel kesit içerisinde, yönetici sınıfın çocuklarını yetiştirmek üzere "müeddib" sıfatı verilen kimselerin görevlendirildiklerini belirtir. Müeddibler, şiir, tarih ve ilahiyat eğitimi vermekteydi. Ardından "Nahiv, tasrif, arûz, belâgat usulü gibi dile hizmet edecek eserlerin te'lîfine girişildikten sonra, bunlar da 'edeb' sözü ile ifade edildiler.” diyen Bilgegil'e göre "Kelime, bu kavram şümûlünü geçen yüzyıla kadar muhafaza" etmiştir. ${ }^{28}$ Dolayısıyla o da edebiyat kavramının güncel anlamının kökenleri için 19. asrı işaret etmektedir. Bununla beraber Berat Açıl yakın tarihli bir çalışmasında, 19. asırdan çok önceki bir dönemde, Kanuni Sultan Süleyman dönemi kadılarından el-Kostantinî'nin Letâifü 'l-efkâr ve Kâşifü'l-esrâr'ında edebiyat kavramını kullandığını tespit etmiştir. ${ }^{29}$ Açıl'ın keşfi, kavramın tarihi açısından önemli olmakla beraber, 19. asır öncesindeki kullanımın ne derece yaygın ve bildiğimiz anlamla ne derece örtüştüğünü kestirmek güçtür. Nitekim Recaizade Talim-i Edebiyat’ta, edebiyatın tarifine dair yürüttüğü tartışmada bu kavramın son beş-on yıldan beri yaygınlaştığını, "zebanzed" olduğunu vurgular. Bu bağlamda Yetiş'in aktardığı örnekte de görüldüğü üzere Kemal Paşazade Said Bey'in Abdülhak Hamid'i hedef aldığı bir yazısında edebiyat kavramını kullanmamasını, kavramın “o vakte gelinceye kadar İstanbul' da adem-i şüyu-1 istimali” ile açıklamas1 ${ }^{30}$ önemli bir ipucudur. Genel itibariyle bakacak olursak o günlerde henüz tam olarak oturmuş bir kavramsal çerçeveden bahsedemiyoruz. Nitekim bir geçiş dönemi söz konusudur. Mektuplaşmanın satır aralarına odaklandığımızda da edebiyat kavramının yeni yeni "zebanzed" olmaya başladığı söylenebilir. Bu açıdan, 17 Haziran 1879 tarihli mektuba baktığımızda edebiyat kavramı şiir ve inşâyı kapsayacak şekilde algılanmaktadır, ancak bunu tekid etmeye de gerek duyulmaktadır.

Bundan evvel takdim ettiğim manzûmeler üzerine "Edebiyat-1 şarkiyyede efkâr-1 asriyyeye göre bir inkılâb îkâ1 tasavvuru takdire şâyan bir emr-i mühimdir" buyruluyor. Edebiyat nazım ve nesrin ikisine de şâmil bir tabir olduğuna ve bunun kısm-1 sânîsince birkaç seneden beri

26 Okay, Batıllılaşma Devri Türk Edebiyatı, 201; Yetiş, Talim-i Edebiyat' in Retorik ve Edebiyat Nazariyatı Sahasında Getirdiği Yenilikler, 144; M. Kaya Bilgegil, Edebiyat Bilgi ve Teorileri: Belâgat, (İstanbul: Enderun Kitabevi, 1989) 1 vd.; Berat Açıl, "Akl-1 Selimden Zevk-i Selime: 'Edebiyat' Kelimesinin İlk Kullanımı ve Anlamı”, Insan ve Toplum, 5/10 (2016) 151-166.

27 M. Kaya Bilgegil, Edebiyat Bilgi ve Teorileri: Belâgat, (İstanbul: Enderun Kitabevi, 1989) 2.

28 Bilgegil, Edebiyat Bilgi ve Teorileri, 2.

29 Açı1, “Akl-1 Selimden Zevk-i Selime: 'Edebiyat' Kelimesinin İlk Kullanımı ve Anlamı”, 151-166.

30 Yetiş, Talim-i Edebiyat'ın Retorik ve Edebiyat Nazariyatı Sahasında Getirdiği Yenilikler, 144. 
vukua gelen inkılâb-1 küllî bir hayli eserler dahi meydana koyduğuna nazaran bu cihetce olan arzu terakkiyâta münhasır ve mesele nazım yolunda dahi inşâ-yı cedîdimizle mütenâsip olacak bir yeni çığır açılmasına aittir zannederim.

Recaizade'nin cevabi ifadelerinden ve alıntısından anladığımız kadarıyla Sadullah Paşa, 16 Temmuz 1879 tarihli mektubunda 'Edebiyat-ı şi'riyyede dahi terakki yalnız şekil ve lafız ile olmaz.” şeklindeki beyanında ise pek de alışık olmadığımız bir tabir kullanmaktadır. "Edebiyat-1 şi’riyye”, günümüze tercümesiyle "şiir edebiyatı" tabiri, edebiyat kavramının tarihinde karşımıza çıkan çeldirici anlam nüanslarından birini akla getirmektedir. Burada edebiyatın, belirli bir alandaki yazılar toplamı (coğafya literatürü, astronomi literatürü vb.) anlamındaki "littérature" karşılığı olarak kullanıldığı, yani Sadullah Paşa'nın kastının şiir literatürü olduğu izlenimi uyanmaktadır.

Öte yandan diğer bir mektupta, “edebiyat-1 Türkiyye” tabirinin kullanıldığı görülüyor. Bu kayıt, günümüzdeki biçimiyle “Türk edebiyatı” tabirinin 1870'li yıllarda kullanımda olduğuna dair bir örnek niteliğindedir. Nitekim o günlerde Ebüzziya' da gördüğümüz üzere “edebiyat-1 Osmaniyye", Namık Kemal'in meşhur yazısından hatırlanacağı gibi "lisan-ı Osmanînin edebiyatı" gibi tabirler daha yaygınd.

Mektupların geneline baktığımızda, sonuç olarak, "şiir ve inşâ" ile "edebiyat" kavramlarının beraber kullanıldıklarını ve henüz tam olarak oturmuş bir kavramsal çerçevenin olmadığını, 1880'li yılların eşiğinde mütereddit bir tablonun bahse konu olduğunu söylemek mümkündür.

\section{Sonuç Yerine}

Bu makalede mektup formunun edebiyat araştırmalarındaki konumundan hareketle Recaizade Mahmut Ekrem ve Sadullah Paşa arasındaki yazışma değerlendirildi. Recaizade Mahmut Ekrem'in incelenen mektuplarına genel olarak bakılırsa ikili arasında ciddi bir diyalogun varlığı göze çarpar. Ancak Sadullah Paşa'nın mektupları ortaya çıkmadıkça burada kurulmaya çalışılan çerçeve kaçınılmaz olarak eksik kalacaktır.

Bu inceleme ile ortaya çıkan veriler Sadullah Paşa'nın o dönemin edebiyat kamusundaki rolü ve etkisini bir miktar daha aydınlığa kavuşturmuş oldu. Diğer yandan yapılan araştırma ve inceleme sonucu, Recaizade Mahmut Ekrem'in Sadullah Paşa'ya yazdığı mektupların buradakilerle sınırlı olmadığı kanaati hasıl olmuştur. Umulur ki yakın zamanda her iki ismin de mektupları ve evrakları ortaya çıkarılarak edebiyat tarihindeki boşluklar doldurulur ve yeni çalışmalara kapı aralanır.

Bu makalenin konusunu teşkil eden vaka, aynı zamanda bizi edebiyat tarihi çalışmalarındaki kaynaklara erişim problematiğiyle de tekrar yüz yüze getirmiştir. Bu çalışmada söz konusu olanlar gibi, ulaşılmaya çalışılan pek çok eser ve belgenin birtakım özel koleksiyonlarda veya arşivlerde saklı durduğu bilinen bir gerçektir. Dolayısıyla en azından kamuya açılması mümkün olan koleksiyon ve arşivler üzerinde gerekli çalışmaların yapılması adına kurumların atacağı adımlar önemli olacaktır. 


\section{EK: MEKTUPLAR}

\section{Recaizade Mahmut Ekrem Tarafından Sadullah Paşa'ya Yazılan 27 Eylül 1877 Tarihli Mektup}

Ma'rûz-1 çâkerânemdir

Meşguliyet mütekessir ve mütenevvi' olunca insanı bazen en mukaddes vazifeleri bile icradan men ettiğini bu defa maatteessüf tecrübe eyledim. Zihinler zaten birçok vakitten beri harp havâdisiyle meşgul ve meşâgil-i resmiyye ve zâtiyye dâim iken sâye-i seniyyede bu defa nâil olduğumuz askerliğe ait işlerin dahi bir yenilere inzımâmı, teveccühü her şeyden kıymetdar ve ubûdiyyeti sermaye-i iftihar olan efendimize bugüne kadar bir arîzacık takdimiyle ihtar-1 nâm-1 müstehâm-1 çâkerâneye meydan vermedi. Halbuki bu şerefli vazifenin ifâsını muhtır ve belki mücbir bazı ahvâl dahi mevki-i zuhura gelmiş idi ki ezcümle birisi zât-ı kemâlâtperverâne-i bî-müdânîlerine mahsus ve emsali görülmeyen bir suret-i fevkalâdede olarak nezdinde sefir bulundukları koca devlet-i imparatoriyyenin bazı azâ-yı hânedânı cânibinden ta demiryol mevkıflarından istikbal ve mazhar-1 tekrim ü ibcâl buyrulmalarıyla umumi ve bi'l-husus bendegân-1 devletlerini fahr ü sürura gark eden muvaffakiyet-i mün'imânelerinin tebrikine müsâraat vazifesi idi. Derece-i meziyyât-1 âliyelerine nispet ettiğim halde azdan az gördügüm bu muvaffakiyet-i aliyyelerini kulunuz fiilen ve kalemen tebrik edemedimse de kalben ve kâlen o işde kat'an kusur etmedim. Şiddet-i hulûs ve ubûdiyyet-i kemterâneme müteallik olan her bir meselenin hakikati nezd-i dakâyık-dânî-i devletlerinde münkeşif ve malum olduğunu bilişim isbat-1 müddeâ yolunda söz söylemekten kulunuzu her vakit iğnâ ettiğini hâtime-i makâl-i sıdk-iştimâl eder ve bi-mennihi'l-kerim şu arîza-i kemterânemin bezm-i sâmîlerine vusûlüne değin hulûl edecek olan 1yd-i said-i fitrı zât-1 âlî-i mün'imânelerine tebrik eylerim. Ferman hazret-i veliyyü'l-emrindir.

Fî 19 Ramazan 94 ve fî 15 Eylül 93 [M. 27 Eylül 1877]

Bendeleri

[Mühür: es-Seyyid Mahmud Ekrem]

\section{Recaizade Mahmut Ekrem Tarafından Sadullah Paşa'ya Yazılan 10 Aralık 1877}

\section{Tarihli Mektup}

Ma'rûz-1 çâkerânemdir

Cevabnâme-i devletlerini şân-1 âlîsine lâyık ta'zimât ile aldım. Hatt-ı dest-i âlîleriyle yazılmış idi. Kulunuz ise efendimizin gerçekten sadık ve meâsir-i kemâlât ü mekâriminin her birine başka başka âşık bir bendesi değil miyim, iltifâtnâme-i devletlerinin o hat ile muharrer olmasından meserret ve mübâhâtim dü-bâlâ oldu. Mükerrer mükerrer okudum. Saatlerce lafiz ve mânâsına hayran kaldım. Ulüvv-i fitrat ve sümüvv-i kadr ü menziletinin hayran-1 ezelî ve 
ebedîsi olduğum zât-1 âlî-i bî-müdânîleri indinde âsâr-1 sıdk u ihlâs-1 kemterânem ne suretle mazhar-1 hüsn-i telakki buyrulduğunun böyle bir bürhan-1 cedid ve celilini müşâhede ile nasıl iftihar etmeyim? Zât-1 mekârim-simât-1 sâmîlerine ez-cân ü dil nasıl müteşekkir olmayım? Vatanımızca ta'mim edilen hizmet-i seyfiyyeden hasbe'l-mevki mahrumiyetlerine mukabil düşmanımızın tahattiyât-1 maneviyesini red yolundaki mesai ve ikdamât-1 cemileleriyle mütesellî oldukları beyan buyruluyor. Vatan bu histe bu fikirde bulunan eâzımın vücuduyla iftihar eder ve öyle zâtlar nerede olsa ve ne mevkide bulunsa kabiliyât-1 fitriyye ve ikdamât-1 hamiyyet-perverâneleriyle vatana büyük büyük fâideler îsar eder. İşte bu mütalaa iledir ki muârefe-i irfan ve kemâlât-ı devletleriyle müşerref olan bendegânınız efendimizi arzu ettikleri mevkide daha şimdiden göremedikleriyçün mütesellî olmaktadır. Buranın hâli dûr-bîn-i fikr-i metîn-i âlîlerine mer'î ve müncelîdir. Saltanat-1 seniyye arzu ve şân-1 âlîsine muvâfik surette bir sulh akdine muvaffak olunca hüsn-i niyeti ve ahâlinin dahi isti' dâd ve kabiliyeti ile tarik-i terakki ve temeddünde az zaman içinde büyük büyük mesafeler kat' olunacağına ve bir yandan dahi maddiyatça mâfâtın telafisiyle iade-i ma'mûriyyet edileceğine ümmidvâr olmasak hâlin icap ettiği esef ve 1zdıraba hakikaten mukavemet olunamayacak. Hemân Cenâb-1 Hakk bu ümmetin muîni olsun. Efendimize ihtâr-1 nâm ve arz-1 ubûdiyyet ne kadar emelim ise şu sırada meşguliyet-i devletlerinin ifratını bildiğim için sık sık tasdi'den ictinab dahi o derece mültezemim olduğundan iltifâtnâme-i devletlerinin cevab-1 teşekkürünü bugüne kadar te'hir etmek mecburiyetinde bulundum. Hâl ve mevki müsait olmadığı halde mücerred biraderim bendelerinin teşviki üzerine mumâileyhe nazire olarak inşad ettiğim manzûmelerden iki kıt'ası belki bir aralık tenezzüh-i efkâr-1 âlîlerine medar olur mütalaasıyla leffen takdim olundu. Iyd-1 meyâmin-bedîd-i adhâyı efendimize tebrik ederim. Emr ü ferman hazret-i veliyyü'l-emrindir.

Fî 28 Teşrinisânî 293 [M. 10 Aralık 1877]

Ekrem Çâkerleri

\section{[10 Aralık 1877 tarihli mektubun ekleri]}

\section{[Gazel]}

Vücûb-1 vahdete her şeyle istişhâd kâbildir

Enel-hakk'1 ana burhân gibi îrâd kâbildir

Hirâsım keşmekeşle çâk-sad-çâk olmasındandır

Elinden gönlümü ol mâhın istirdâd kâbildir

Taazzür varsa terk-i mâsivâ etmektedir ancak

Başım her bir belâdan eylemek âzâd kâbildir 
Hüner vâreste etmektir tedâbiri tehallüfden Teşebbüs kâr-1 sa'be her-çi bâd-â-bâd kâbildir

Büyüklük zâten isbât-1 tefevvukdur bize yoksa Senin'çün mesned-i ikbâle istis'âd kâbildir

Gönülde hâhiş olsa manevî sâr almağa senden Bil ey gaddâr kim giryemden istimdâd kâbildir

Müsâid devrine pek de güvenme âlemin zâlim Seni mahvetmeye bir gün ettiğin bî-dâd kâbildir

Mizâc-âmûz-1 eşyâ mürşid-i kâmilden ihbâr et Gürûh-1 dâllîni eylemek irşâd kâbildir

Sakın ifrât u şiddetden harîm ol ey mürebbî kim

Salâha sevk ederken âdemi ifsâd kâbildir

Sükût icâb eden ümmid-i istikbâldir yoksa

Bizim'çün hâlden her vechile feryat kâbildir

Vazifen âlemi i'mâra himmettir senin ancak

Demek düşmez ola bir gün harâb-âbâd kâbildir

Biraz da gel anı dinle gıyâbından ne söylerler Vicâhen izz ile ettirmek ismin yâd kâbildir

Değilse borcumuz bir tarz-1 ceyyid bulmak ahfâda Edeb de'binde hıfz-1 meslek-i ecdad kâbildir

Ümidin kesme Mevlâ'dan eğer ömrün müsâidse Dil-i nâ-şâdın Ekrem bir gün olmak şâd kâbildir

$$
* * *
$$

\section{[Gazel]}

Hiddetle ârızında reng-i hicâb göster

Mirrîh ile hem-âgûş bir mâh-tâb göster 
La'l-i lebinden ey meh donmuş şarâb göster

Tebhâleden yüzünde şekl-i habâb göster

Ben ağlasam da bakma sen hande-rîz-i nâz ol

Gül-gonçe-i feminden lu'lû-yi nâb göster

Gönlümde tâ-kıyâmet bin ukde zâhir olsun

Her târ-1 perçeminde bir pîç-tâb göster

Arz et nasıl olurmuş dünyâda fitne nâim

Çeşmân-1 cân-sitânın mahmûr-1 hâb göster

Zevk-âşinâ-yı hüsnün birdir yanında lutfu

İster güleryüz ister vaz'-1 itâb göster

Lutf u mürüvvetinden ger yoğ-ise nasibim

Cevr ü gamında olsun zâlim nisâb göster

Sâkînin öp ayağın lâ-ya'kıl ol da sonra

Cemşîdvâri kendin âlîcenâb göster

Şâyed masûn olursan ta'rîz-i nâ-becâdan

Ekrem cihâne kendin mest-i harâb göster

$* * *$

Evvelkinin ekser-i ebyâtı yeni, diğeri ise tamâmiyle eski fikre tâbidir.

\section{Recaizade Mahmut Ekrem Tarafindan Sadullah Paşa'ya Yazılan 17 Haziran 1879 Tarihli Mektup}

Ma'rûz-1 çâkerleridir ki

Cevabnâme-i sâmî-i mün'imânelerini dest-i ta'zim ile aldım. Tasvir-i âlî-i âsafâneleri dahi melfuf idi. Bu ihsân ale'l-ihsân-1 bende-perverîleri fitrat-1 cemîle ve seciyye-i kerîme-i ehillâ-nüvâzîleri meâsir-i ber-güzîdesinden olarak itimat buyrulsun ki kulunuzu ihyâ eyledi. Binaenaleyh keremnâmelerini defaatle okudum. Tasvir-i âlîlerini dahi nazar-1 ahkarânemin mahall-i in'itaf-ı dâimîsi olacak bir câ-yı tekrime vaz' eyledim. Ahlâk-1 fâzıla-i devletlerini tezyin eden mürüvvet ve nezaket-i sâmîlerinin derecâtını âcizâne takdir etmiş idim. Bununla beraber resm-i âlîlerini arîza-i kemterânemin ona dâir olan fikrası dahi delâlet eder ki cesaretsizlikle 
istemiş idim. O cesaretsizliğim bugün mürüvvet-i seniyyeleri karşısında büyük bir mahcubiyete münkalib oldu. Bu lutf-1 devletlerine arz-1 şükran etmek isterim fakat tabir-i lâyıkını bulmaktan âcizim. Çünki ne kadar çalışsam yine vicdanımın hissiyat-1 şükraniyyesini tarife muktedir olamayacağım. Binaenaleyh tefsir-i mânâsını belâgat-i fehm-i felâtûn-pesend-i sâmîlerine havale ederek şu iki kelimeyi yazıyorum: Müteşekkir-i ihsanlarıyım. Tasvir-i âlîlerine nazaran vücud-1 sâmîlerinde nümâyân olan âsâr-1 semenden fevkalâde memnun oldum. Demek olur ki Berlin'in âb u hevâsıyla imtizac buyurmuş. Avrupa'ya seyahat arzû-yı ahkarânem bu sene dahi pezîrâ-yı husul olamadı. Şayet hâsıl olaydı Berlin'e geldiğim halde nâil-i telattufât-1 mihmân-nüvâzîleri olacağım derkâr idi. Kulunuza ise öyle bir yerde hâk-pây-1 sâmîleriyle müşerref olmaktan büyük bir nimet olamaz. Ne çare ki insan bazı vakit kendi bildiğinden ziyade âciz ve nâtüvân imiş.

Bundan evvel takdim ettiğim manzûmeler üzerine "Edebiyat-1 şarkiyyede efkâr-1 asriyyeye göre bir inkılâb îkâı tasavvuru takdire şâyan bir emr-i mühimdir” buyruluyor. Edebiyat nazım ve nesrin ikisine de şâmil bir tabir olduğuna ve bunun kısm-1 sânîsince birkaç seneden beri vukua gelen inkılâb-1 küllî bir hayli eserler dahi meydana koyduğuna nazaran bu cihetce olan arzu terakkiyâta münhasır ve mesele nazım yolunda dahi inşâ-yı cedîdimizle mütenâsip olacak bir yeni çı̆̆ır açılmasına aittir zannederim. İnşâda zincirleme ibareler terk ve lüzumsuz sanâyi-i lafziyyeye bedel selâset-i ifade ve selâmet-i mânâ yolları iltizam olunalı sevilir ve lezzetle okunur ufak tefek bir çok âsâr vücuda geldiği inkâr olunamaz. Halbuki şiirimizi eski yoldan çıkarmak ve binâenaleyh tabii ve hakiki şiir söyleyebilmek için ne yapmak lazım geleceği henüz taayyün edememiştir. Bazı efkâra göre evzân-1 Arabiyyeyi terk ile yerine bizim kahve şairlerinin kullandıkları parmak hesabını kabul etmeli imiş. Fikr-i âcizânem de böyledir. Çünki lisan-1 Osmânînin şivesiyle ma’hud vezinler imtizac edemiyor. Müsellemdir ki şiirimizin en büyük meziyeti tumturak-1 elfazdan ibarettir ki dikkat olunursa şuarâmızı bu cihete ziyade itinâ ettiren de evzânın tabiatidir. Bir kere parmak hesabı yani aded-i hecâ usulü ittihaz olunursa artık tumturak-1 lafz merakında devam kâbil olamayacağı misillü tetâbu-i izâfât gibi gayr-1 me'nûs kelimeler isti'mâli gibi seyyielere de meydan kalmayacağından fesâhat ve belâgat cihetlerine dikkat olunmakla beraber letâfet-i meâl ve müeddâ yolları hâssaten iltizam olunarak nazım için de bir şahrâh-1 cedid-i terakki açılmış olur. "Bu yolda edilebilecek tecrübe-i sahîha üdebâ-yı garbın eş’ârımızda naziri olmayan âsâr-1 nazmiyyesini tanzir ve taklit etmektir" yolundaki ifade-i devletleri muvâfık-1 hikmet ve hakikattir. İşte bunun için eş’ârımızın şekli de değişmek iktizâ eder. Edebiyat-ı cedide meraklılarından bir zâtın parmak hesabı üzerine telif ettiği bir tiyatro, "efâîl ü tefâilden başka bir harekât ve sekenâta tâbi olan söz mevzun değildir" itikadında bulunanlara göre imâle-i nazara bile şâyan görülmüyorsa da kulunuzun rey-i ahkarâneme göre tabii şiir heveskârları için numûme-i imtisal olmağa lâyıktır. Vâkıâ bu tiyatronun birçok fena yerleri var fakat bir hayli güzel parçaları da var ki hatırımda kalan şu iki beyit onlardandır: "Rabbimin Hakîm ismine bin kasem / Ki sen hekîmim olacağını bilsem / Günde bin hastalık niyaz ederdim / Her gün bir yeni derdim olsun derdim" Bu söz âdîdir fakat 
bizim şuarâmızın âsâr-1 muteberesi içinde bu şivede bu selâsette bu belâgatte bir söze nâdiren bile tesadüf olunamıor. Mektub-1 devletlerinin "Kabâil-i Türkiyye tarik-i medeniyete dâhil oldukları zaman şuarâsı âsâr-1 Arap ve Acemi taklit ederek edebiyat-1 Türkiyye’yi tevsi’ ettiler. Hayfâ ki şiirimizin hâssa-i kavmiyyesini bu inkılâb esnasında muhafaza edemediler” fikrası mübâhasât-1 edebiyyede zuhura gelen ihtilâfât-1 kesîrenin birçoğunu def' ve izâle edecek bir keşf-i müdakkıkâne ve binâenaleyh tetkikat-ı edebiyye ile tevaggul edenler tarafindan efendimize câlib-i teşekkürdür. Şüphe yoktur ki edebiyatımız ibtidâdan kavmiyyetini muhafaza edeydi bugünkü terakkiyâtı kendi dairesi içinde efkâr-1 asriyyeye tâbi olup gitmekten ibaret olurdu. Bu bahisler filhakika bir mektup havsalasına sığamaz. Mamâfih ihsannâme-i devletlerinin fikarât-1 muhtasara-i edebiyyesinden küllî istifade hâsıl olmuştur. Bundan dolayı dahi hâk-pây-1 sâmîlerine arz-1 vecîbe-i şükrana müsâraat ederim. Elde başlanmış bazı şeyler olduğundan bahis buyruluyor. İnşaallah ikmâl buyrulduğunda kulunuza ihsan buyrulursa ba'de'l-istinsah asıllarını yine efendimize iade eder ve müsaade buyrulursa teksir-i nüsahı için isteyenlere dahi veririm. Bizim âsâr-1 nefîse meraklılarında bir hâssa var, ellerine geçen nevâdir-i edebiyyeyi nakd-i hasis gibi çekmecelerde hapsediyorlar. Bazı zevâta yazılmış mekâtib-i edîbânelerinin evsafını işittiğim halde hiçbirisini ele geçirmek kâbil olamadı. Resm-i hakîrânemin talebi zımnındaki telattuf ve iltifat-1 devletleri başkaca mûcib-i fahr u meserretim olarak emr-i âlîlerine imtisâlen ve zât-1 sâmîlerine fart-1 tahassür ve iştiyak-1 kemterânemi arz u beyana müekkelen irsal-i bezm-i sâmî-i mün'imâneleri k1lındı. Emr ü fermân hazret-i veliyyü'l-emrindir. Fî 5 Haziran 295. [17 Haziran 1879]

Ekrem Bendeleri

\section{Recaizade Mahmut Ekrem Tarafından Sadullah Paşa'ya Yazılan 7 Ağustos 1879 Tarihli Mektup}

Ma'rûz-1 çâkerânemdir

4 Temmuz 95 tarihli inâyetnâme-i devletlerini dahi aldım. Hulûsa dair sözler samimi dahi olsa mükâtebât-1 dostânede o kadar karin-i makbuliyet olamaz. Hususiyle teâtî-i efkâr-1 edebiyye ile gayet vâsi, gayet feyizli bir zeminde şekl-i dîger alan muhâberâtta o makule sözlere hiç mahal görülemez. Fakat tevâlî-i telattufât-1 seniyyeleriyle tahassul eden telezzüzât-1 vicdaniyye, hissiyat-1 şükraniyyeme müteallik iki kelime olsun yazmamak bendenizce bir azab-1 elim olduğundan bu bâbda bir kere daha mazhar-1 iğmaz olmaklığımı istirham ederim. Teveccühât-1 devletlerini kazanmak bendenizce aksâ-yı metâlib idi. Çünki efendimizi kemâlât ve fezâil-i insaniyyece pek büyük ve binaenaleyh teveccühât-1 sâmiyyelerini sermaye-i iftihar bilirim. Bu matlab-1 çâkerânem hâsıl olduktan sonra emelim onun devamına münhasır ve kalb-i ahkarânem taraf-1 devletlerinden câ-be-câ iltifat görmeğe müftakir bulunurdu. Âmâl-i hâlisa-i vicdaniyyemde ne garip terakkidir ki o câ-be-câ mazhariyetine müftakir ve o suretle müftehir olduğum telattufâtın bir zamandan beri hiç eksik olmamasını istiyorum. Efendimize daima arîzalar takdim edeyim, 
cümlesinin cevaplarına nâil olayım diyorum. Bir arîza takdim edince cevabını pek tatı bir intizar ile bekliyorum. İhsannâme-i devletlerini alınca defaatle okuyorum, saatlerce elimden bırakamıyorum. Fıkarât-1 bende-perverânesinden o kadar kesb-i sürur ediyorum ki tavsifi nâ-kâbil. Mündericât-1 edebiyyesinden o derece lezzetyâb oluyorum ki tarifi müstahildir. İște bu defaki keremnâmelerini dahi o vechile telakki eyledim. Fehâvâ-yı latîfesi emsaline fâik, mezâyâ-yı edebiyyesine lübb-i hikmet ve hakikat denilse lâyıktır. Binâenaleyh bu inâyet ve himmet-i devletlerine de suret-i mahsusada arz-1 kemâl-i teşekkürle beraber saded-i bahs olan edebiyatımızın terakkisi hakkında yine bazı mütalaât îrâdına cesaret edeceğim. Mülâhazât-1 kâsırânem red ve kabul-i âlîlerinden hangisine mazhar olsa kulunuzca mûcib-i teşekkürdür. Red buyrulursa tashih-i fikr ü nazara medardır. Kabul buyrulursa bendeniz için ne büyük iftihardır.

“Edebiyat-1 şi' riyyede dahi terakki yalnız şekil ve lafız ile olmaz. Tab'-1 selimin hissiyatını bir kat daha i'lâ edecek usul-i terbiye ile olur. Demek olur ki terakkiyât-1 edebiyye terakkiyât-1 terbiye ile mütenâsiptir" buyruluyor. Bu hakikatler hiçbir vakitte inkârı kâbil olan şeylerden değildir. Fakat terakkiyât-1 edebiyye şâhrâhında ilk hatvemizi atmak için tağyir-i usule ihtiyac-1 kat'i ile muhtaç olduğumuzdan -şekil ve lafız- dediğimiz şeyin terakkiyât-1 terbiyeye nispeten akdem ve binâberin ziyadesiyle ehem olduğunu dahi teslim etmek iktizâ eder. Her millette halkın tasfiye-i vicdan, terbiye-i efkârına hizmet eden kendi üdebâsı değil midir? Alelıtlâk terbiye-i umumiyede ulûm ve fünûnun tesirâtını teslim etmemeğe çare yoktur. Ancak edebiyatın terakkisine hâdim olacak erbâb-1 isti' dâd ve kabiliyetin perveriş-yâb-1 kemâl olmaları kendilerinden evvel gelen üdebânın âsâr-1 kalemiyyesini tetebbu sayesindedir. Bizim edebiyatca eser-i kudemâya iktifâ ile bir eser-i terakki gösteremediğimiz malum ve bunu erbab-1 isti'dâdın fikdânından ise usul-i atîkanın adem-i müsaadesine hamletmek makuldür. Zira efendimiz gibi milletin muktedâ-yı irfân ve mürebbî-i vicdanı olan bazı zevâtın usul-i inşâda ağlâl-i efkâr olan teselsül-i ibârât ve teâkub-1 revâbıt kayıtlarını darb-1 hâme ile kırmak ve tekellüfât-1 zâide ve melâib-i lafziyye mânialarını bütün bütün tarh u ref' etmek ile îkâ' ettikleri inkılâbı hüsn-i telakki eden müstaidân-1 vatan, yazı yazmak nasıl olduğunu gördüler. Bazıları derece-i terbiye ve malumatlarına göre ele alınabilir, lezzetle okunur birtakım eserler dahi meydana koydular.

Şiirimize gelince, o yolda henüz bir meslek-i cedid açılamadığından mahdud ve merdud olan daire içinde yuvarlanıp gidiyor. "Her milletde nâzım çok bulunur ama şair nâdirdir" kaziyesi malumdur. Lâkin usûl-i hâzıra hükmünce bizde nâzım dahi yetişemeyecek gibi görünür. Meselâ Fransızlarda La Fontaine'lerin veyahut Florian'ların hikâyât-1 manzumeleri gibi bir eser vücuda getirmeğe şimdiki hâlde hangi şairimiz muktedir olabilir. İște bu mülâhazâta mebnî idi ki edebiyatca inkılâp îkâ'1 lüzumuna müteallik bahisde kulunuz "Nesir cihetince olan arzu terakkiyâta münhasır ve asıl mesele nazım yolunda dahi inşâ-yı cedidimizle mütenâsip bir yeni çı̆̆ır açılmasına aittir" demiş idim. Filhakika bugünkü tarz-ı inşâmızla efkâr ve âdâtın müsait olduğu derecede bir güzel roman yazılabilir. Lâkin fâilâtün mefâilün yolunda eğri büğrü ifâdât ve lisanımızın tabiatine gayetle mugâyir olan imâlât ve sâir birçok tekellüfât ile manzum bir tiyatro meydana konulamaz, konulsa da makbul olamaz. 
Bizde muâheze âdetinin fikdânı edebiyatta terakki edememekliğimizin cümle-i esbâbından ma'dud olunca bazı mamûlât-1 sınâiye üzerlerine konulan etiketler gibi umumun nazar-1 temyizine arz olunmuş bir eserin evvel veya âhirine derc olunmak için şundan bundan takriz dilenciliği âdetine ne demeli? Bir eserin haddizâtında hiçbir değeri yoksa birkaç kişinin birer sebep veya mecburiyetle senâ-hânlık etmesi ona bir meziyet ilave edemeyeceği gibi zaten makbul olan bir eser umum nazarında kesb-i itibar etmek için her tür takrizâtdan müstağnidir. Şu kadar ki “bir şeyi yed-i icadından mükemmel olarak çıkarmak Allah'a mahsus” olduğiyçün âsâr-1 beşerde kusurluluk zaruridir. Binaenaleyh bir eser-i edebî meydana gelince ona bakılır, eğer kemâlâtı sakatâtına galip yani heyet-i mecmuası itibariyle âsâr-ı mutebereden ma'dud ise kusurları neresindedir, bunu halka göstermek için kalemine, iktidarına güvenenler tarafından muâhezeler yazılırsa elbette fâide-i kesîresi görülür. Bu cihetle muâheze-i edebiyye âdetinin bizde dahi zuhurunu tervic muvâfik-1 hikmettir.

Critique littéraire tabirini o yolda eserleriyle cümleye müsâbakat edenler muâheze-i edebiyye diye tercüme ettiler. Edebiyat-1 cedîde ile uğraşanlar beyninde bugünkü günde tabirât-1 müsta'meledendir. Başka tabir aramağa hâcet yoktur zannederim. Bâkî bekâ-yı teveccühât-1 devletleri ehass-1 metâlib-i çâkerânemdir. Emr ü fermân hazret-i veliyyü'l-emrindir. Fî 26 Temmuz 95 [M. 7 Ağustos 1879]

Ekrem Bendeleri

\section{Recaizade Mahmut Ekrem Tarafından Sadullah Paşa'ya Yazılan 13 Haziran 1884 Tarihli Mektup}

Mekârim-perdâz asdikâ-nüvâz devletlü efendimiz hazretleri

İltifâtnâme-i nâmî-i mün'imâneleri ki 5 Haziran 1884 tarihli idi resîde-i dest-i ta’zim oldu. Ferâiz-i ubûdiyyetten olan takdim-i ma'rûzât emrinde bir hayli zamandan beri vuku bulan taksirât-1 kemterânemden iğmâz-1 ayn ile çâker-i ihlâs-perverlerini müstağrak-1 taltîfât buyuran mürüvvet-i âlîcenâbâneleri nasıl tavsif olunsun ve bu sebeple husûle gelen mesrûriyyet-i çâkerânem ne türlü tarif edilsin ki ikisi de derece-i tasavvurdan bâlâ-terdir. Eser-i hakîrânem hakkında ibraz buyrulan lutf-1 takdir-i âlî ve hüsn-i teveccüh-i sâmîlerine de ne yolda teşekkür edeceğimi bilmekten âcizim. Zât-1 fezâil-simât-1 devletlerine mertebe-i tereddüd-i âcizânem arz-1 meâsir-i ubûdiyyette taharrî-i vesâil ve vesâitden müstağnî iken Zemzeme'yi takdimde Said Beyefendi Hazretlerinin inâyetlerine müracaatım taksîrât-1 vâkıamdan dolayı nezd-i âlî-i âsafânelerinde ziyâdesiyle mahcub olduğumdan neş'et etmekle bu kusurun dahi karin-i afv-1 sâmîleri olacağını ümid ederim. Mecmûa-i eş’âr-ı nâçizânem içinde bazı şeyler gerçekten nazar-1 takdir-i sâmî-i nefâyis-pesendâneleri olmuş ise bu muvaffakiyet bendelerince nihayet derecede fahr ve teşekküre sezâdır ki takdir-i devletleri hakikaten her hususta bir mi'yâr-1 sıhhat-intimâdır. Zemzeme'nin birincisinden dahi bir nüshasının takdimiyle kesb-i mübâhât olunur. Şarkın en muazzam en muhterem bir lem'a-i zekâsı matla'-1 kemâline neşr-i envâr-1 
füyûz edecek yerde mağrib-i vukufda istikrâr-nümâ bulunmak dâğ-efrûz-1 kulûb-1 asdikâdır ki bu bahsi tafsile mecalsizlik hüveydâdır. Ne ise, bâkî arz-1 ta'zimât ve teşekkürât ile bekâ-yı teveccühât-1 maâlî-gâyât-1 devletlerini istid'â eylerim. Emr ü fermân hazret-i veliyyü'l-emrindir. İstanbul'dan Viyana'ya. Fî 13 Haziran 1884

Ekrem Bendeleri

\section{Mektupların Zarflarından Bir Örnek}

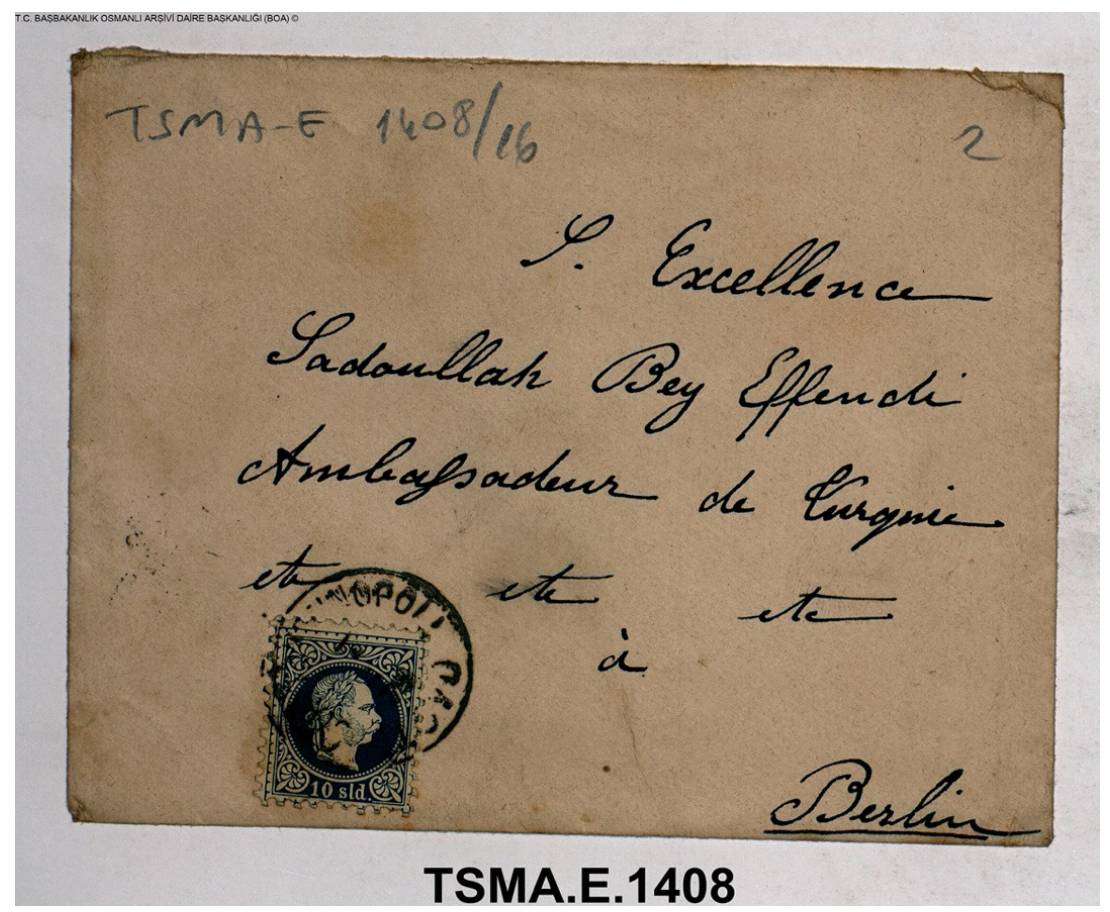

Hakem Değerlendirmesi: Dış bağımsız.

Çıkar Çatışması: Yazar çıkar çatışması bildirmemiştir.

Finansal Destek: Yazar bu çalışma için finansal destek almadığını beyan etmiştir.

Teşekkür: Çalışmanın hazırlık sürecinde yardımlarını esirgemeyen Prof. Dr. Ali Akyıldız, Prof. Dr. Ali Şükrü Çoruk, Doç. Dr. Berat Açıl, Murat Serdar Saykal ve Abdullah Okal'a teşekkür ederim.

Peer-review: Externally peer-reviewed.

Conflict of Interest: The author has no conflict of interest to declare.

Grant Support: The author declared that this study has received no financial support.

Acknowledgement: I would like to thank Ali Akyıldız, Ali Şükrü Çoruk, Berat Açıl, Murat Serdar Saykal and Abdullah Okal for their help during the preparation of this article. 


\section{Kaynaklar/References}

\section{Arşiv Belgeleri}

Devlet Arşivleri Başkanlığı Osmanlı Arşivleri (BOA), Topkapı Sarayı Müzesi Arşivi Evrakı (TS.MA.e), 1408.0016 H-18.08.1296.

İstanbul Şehir Üniversitesi Taha Toros Arşivi, "Recaizade Mahmud Ekrem tarafından Viyana'da resmi bir kuruma gönderilen mektup”, Erişim: 01.06.2020 http://earsiv.sehir.edu.tr:8080/xmlui/handle/11498/19805

\section{Kitap ve Makaleler}

Açıl, Berat. "Akl-1 Selimden Zevk-i Selime: 'Edebiyat' Kelimesinin İlk Kullanımı ve Anlamı”, Insan ve Toplum, 5/10 (2016) 151-166.

Ahmet Mithat Efendi, Avrupa'da Bir Cevelan, haz., N. Arzu Pala, İstanbul: Dergâh Yayınları, 2015.

Akyıldız, Ali. Sürgün Sefir Sadullah Paşa, İstanbul: Türkiye İş Bankası Kültür Yayınları, 2011.

Ayaşl1, Münevver. İşittiklerim, Gördüklerim, Bildiklerim, İstanbul: Boğaziçi Yayınları, 1990.

Bilgegil, M. Kaya. Edebiyat Bilgi ve Teorileri: Belâgat, İstanbul: Enderun Kitabevi, 1989.

Enginün, İnci. Abdülhak Hâmid'in Hatıraları, İstanbul: Dergâh Yayınları, 1994.

İnal, İbnülemin Mahmut Kemal. Son Asır Türk Şairleri, İstanbul: Milli Eğitim Basımevi, 1969.

İbrahim Şinasi Efendi, "Münacaat”, Yeni Türk Edebiyatı Metinleri 1: Şiir, haz. İnci Enginün, Zeynep Kerman, İstanbul: Dergâh Yayınları, 2011.

Mehmed Galib Bey, Sadullah Paşa Yahud Mezardan Nidâ, haz. Nazir Akalın, İstanbul: Dergâh Yayınları, 2003.

Okay, Orhan. Batılılaşma Devri Türk Edebiyatı, İstanbul: Dergâh Yayınları, 2011.

Recaizade Mahmut Ekrem, “Mukaddime”, Hazîne-i Evrak, 1, (1 Mayıs 1297 [13 May1s 1881].

Recaizade Mahmut Ekrem, Talim-i Edebiyat, İstanbul: Mihran Matbaası: 1299 [1882].

Recaizade Mahmut Ekrem, Takrizat, İstanbul: yy., 1314.

Recaizade Mahmut Ekrem, Nâçiz, İstanbul: Mahmud Bey Matbaası, 1302.

Recaizade Mahmut Ekrem, Şiirler, haz. Hakan Sazyek, Esra Sazyek, Betül Solmaz, Kocaeli: Umuttepe Yayınları, 2019.

Tansel, Fevziye Abdullah. Namık Kemal'in Hususi Mektupları: İstanbul Avrupa ve Magosa Mektuplarl, Ankara: Türk Tarih Kurumu, 1967.

Yetiş, Kâzım. Talim-i Edebiyat'ın Retorik ve Edebiyat Nazariyatı Sahasında Getirdiği Yenilikler, Ankara: Atatürk Kültür Merkezi, 1996.

Yücel, Hasan Âli. Edebiyat Tarihimizden, İstanbul: İletişim Yayınları, 1989. 